\title{
Some Issues of Improvement of the International Cooperation of Prosecutors Office of the Republic of Uzbekistan Under Digital Globalization
}

\author{
Rakhimov F. Kh. ${ }^{1,}$ Valijonov D.D. ${ }^{2,3, *}$ \\ ${ }^{1}$ Academy of the General Prosecutors Office of the Republic of Uzbekistan, Tashkent, Republic of Uzbekistan \\ ${ }^{2}$ Tashkent State University of Law, Tashkent, Republic of Uzbekistan \\ ${ }^{3}$ University of World Economy and Diplomacy, Tashkent, Republic of Uzbekistan \\ *Corresponding author. Email: valijonov.daler@mail.ru
}

\begin{abstract}
The article focuses on the issues of international cooperation of the Prosecutors' Office on provision of legal assistance in criminal matters. Besides that, the article is dedicated to the matters concerning the cooperation Prosecutors' Office in terms of fighting against crime within the regional scope of international organizations.

The authors of this scientific article revealed the essence and main directions of international cooperation of the Prosecutors' Office of the Republic of Uzbekistan to combat transnational crime and corruption in the context of digital globalization and the integration of the world community. In particular, in this scientific research, proposals were made to improve the system of wanted persons, as well as the cancellation of biometric passports.
\end{abstract} Keywords: international cooperation, legal assistance, criminal prosecution, extradition, regional organizations,

digital globalization, digital integration, cancellation of biometric passport

\section{INTRODUCTION}

The integration processes taking place in the modern world have a significant impact on the economy and politics, setting new challenges for countries. It should be noted that the annual increase in the provision of mutual legal assistance by the member states of the CIS (Commonwealth of Independent States) and the SCO (Shanghai Cooperation Organization) on criminal prosecution and extradition of persons is an objective reality, a consequence of the expanding interaction between law enforcement agencies of the states participating in these organizations.

Strictly noting, the issues of extradition of a criminal (extradition) refers to international, and not to national legislation. It is here that its main provisions are developed. In practice, the interests of the fight against crime, especially taking into account modern means of communication that facilitate flight abroad, have forced most states to conclude a whole network of agreements on the mutual extradition of a criminal (extradition).

Besides that, the active development of the area of cooperation under consideration in recent years, as well as the improvement of international legal norms and domestic legislation in the field of criminal process objectively determine the urgent need to improve the institution of extradition, criminal prosecution and other forms of legal assistance in criminal matters, as in legislative and at the law enforcement level.

In its most general form, the concept of extradition can be defined as the transfer of persons who committed crimes, from one state (requested) in whose territory they are located to another state (requesting), in whose territory the crime was committed or of which the offender is a citizen.

Understanding the legal nature of extradition is not the same. Some scholars believe that the extradition of criminals is a purely administrative matter, because often the decision on it is not made by the court, but by the government or any of its organs [1].

Domestic legal scholars at the beginning of the last century have already recognized that "at present, all the interest of international criminal law is concentrated in the doctrine of extradition" [2].

Moreover, our contemporaries, analyzing the course of history, began to note the fact that "... the periodization of international criminal law begins, which coincides with the well-known periodization of international law in general" [3].

In modern legal science, it is determined that the institution of extradition ".. is a set of regulatory requirements 
governing the transfer of the person who committed the crime from one (requested) state to another (requesting) state to bring to criminal responsibility and (or) serving a sentence". The following characterizing feature is noted: "the institution of extradition of a person ... as an institution of law is distinguished by the complexity of the legal components that determine its nature" [4]. These components and determining elements are:

- norms of conventions governing treaties on legal assistance and legal relations between states;

- usually-legal norms that arose because of prolonged interaction of states, prescribing proper behavior and recognized as legally binding;

- national (domestic) legal standards.

The very concept of extradition of a person for criminal prosecution or execution of a sentence, representatives of legal science offer many definitions.

In addition, when interviewing a detained person, the prosecutor receives detailed explanations from him about the places of stay (residence) in Uzbekistan. Based on the information received, he seeks information confirming these circumstances from the territorial divisions of the Ministry of Internal Affairs of the Republic of Uzbekistan.

The prosecutors verify the authenticity of the documents held by this person, establish his identity and citizenship, and demand information on the possible belonging of the detainee to the citizenship of the Republic of Uzbekistan. At the same time, the prosecutor checks the availability and authenticity of the data, taking into account which extradition of a person may be refused or extradition may be delayed.

The legislator in Art. 603 of the Code of Criminal Procedure of the Republic of Uzbekistan specifies circumstances excluding extradition. If at the time of the person's detention there is no data excluding the extradition of the detainee, the prosecutor shall ensure that such person is detained for 72 hours.

According to the norms of the United Nations Convention against Transnational Organized Crime, and a number of other international treaties of the Republic of Uzbekistan on extradition, the requested party applies domestic law when detaining a person to ensure his extradition.

In this regard, ensuring the rights of detainees of this category, the interrogating officer or investigator draws up a detention protocol in compliance with the requirements of the Code of Criminal Procedure of the Republic of Uzbekistan. When drawing up the detention protocol, the person is explained the reasons for the detention, the right to receive a copy of the detention protocol, the right to give explanations on issues related to the extradition procedure, including in the native language, or the language that he speaks, or refuse to give explanations.

Moreover, the decision of the competent authority of a foreign state on sending a request for extradition, on detention, or a verdict that has entered into legal force, is brought to the attention of the detained person.

Now we will discuss some differences in the criminal procedure legislation of the CIS member states.

A study of the judicial and investigative practice of the Republic of Uzbekistan leads to the conclusion that the reason for the cancellation by the courts of extradition decisions is mainly incomplete compliance with the conditions provided for in Art. 601 of the Code of Criminal Procedure of the Republic of Uzbekistan (as well as relevant international treaties) under which the Republic of Uzbekistan can extradite foreign citizens or stateless persons from its territory to a foreign state for criminal prosecution or execution of a sentence.

According to Art. 601 of the Code of Criminal Procedure of the Republic of Uzbekistan, extradition of a person can be made, in particular, when the foreign state that sent the request can guarantee that the person against whom the request for extradition is sent will be prosecuted only for the crime specified in the request, and after the end of the trial and the sentence will be able to freely leave the territory of this state, and also will not be sent, transferred, or extradited to a third state without the consent of the Republic of Uzbekistan.

At the same time, in the criminal procedure legislation of a number of CIS member states, there are currently no rules obligating to give the above guarantees when sending requests for extradition.

However, in the criminal procedure legislation of a number of CIS countries there are other differences that negatively affect the extradition process.

In particular, in Georgia, Ukraine and Moldova, judges under the current criminal law can decide on the detention of the wanted person for only a month, which is obviously not enough to solve extradition issues in the states that detained the wanted persons.

Extradition procedures should be extremely short, but provided with convincing evidence and not contradict national legislation.

Practice shows that there are still not a few cases of inaccuracies in the translation of materials of criminal cases sent abroad into the language of the requested party, the lack of translation of all materials of the case, improper certification of investigative materials, including the official seal. In some criminal cases, the investigation period is extended without taking into account the time required for these cases to be received by the law enforcement authorities of the requested state.

A significant problem remains the question of the timeliness of sending the state, the initiator of the search for a person in order to extradite him for criminal prosecution.

The delay in providing the state requesting the issuance of the necessary documents reduces the effectiveness of the interstate criminal investigation, forces time and resources to organize a re-search, which, as a rule, is ineffective. 
In connection with the stated shortcomings in the application of the aforementioned provisions of the Minsk Convention by a number of CIS member states, it is advisable, in our opinion, to raise questions about improving the exchange of information on databanks of the regional wanted lists of neighboring states and about introducing compensation provisions into the Minsk Convention of January 22, 1993 the country initiating the search for financial costs for the maintenance of foreign citizens detained on an interstate search, in case of untimely submission of the necessary documents requesting party.

It is no coincidence that issues related to extradition are given a separate chapter 65 of the Code of Criminal Procedure of the Republic of Uzbekistan. The development and improvement of this institution is dictated by the urgent needs of practice. Considering the problems of extradition, experts note two trends in the current practice of extradition.

On the organizational and practical part, a number of organizational measures should be proposed to improve the interaction and cooperation of law enforcement agencies:

- it will be advisable to organize training seminars and meetings on the exchange of information between law enforcement officials;

- to have a good command of a foreign language in order to allow communication between prosecutors without intermediaries;

- expand the use of electronic means of information exchange, including video conferencing methods;

- organize workshops with representatives of states on issues of mutual assistance and general problems of criminal justice.

Regarding the procedural part, it is necessary to solve some procedural aspects related to the extradition procedure. In practice, in relation to persons subject to extradition, the following procedure for the participation of counsel has developed. According to the norms of the Code of Criminal Procedure of the Republic of Uzbekistan, a defender is allowed from the moment of detention. We believe that the participation of the defense counsel should be ensured when the person is to be extradited, since it is often necessary to challenge the grounds for detention, to provide legal assistance, to protect the rights relating to the rules of detention, and some others. In this connection, the question arises: should states participate in the case?

For example, A.I. Boytsov proposes to provide for the participation of a foreigner's lawyer in the Code of Criminal Procedure [5].

Given the fact that the investigation is being conducted in the requesting state, the participation of the defender of that state is also advisable. It seems that this is not quite the right approach, since detention will take place anyway according to the norms of the national legislation of another state. In this situation, the benefit of a defender of a foreign state will be minimal.
In addition, according to the norms of a foreign state, a defender can be allowed to work and not from the moment of arrest or detention of a person, as provided for in the Criminal Procedure Code of the Republic of Uzbekistan, but at a different stage. This means that the participation of a defender of a foreign state in the implementation of detention for extradition may not be feasible at all.

In resolving issues of extradition, when the most "dense" and active interaction of the subjects of criminal prosecution of various states is carried out, the prosecutor's office and the preliminary investigation bodies play a leading role and are an integral (unconditional) element in the legal mechanism of international cooperation in the field of criminal proceedings.

On the legislative side, it is proposed to sign and ratify the Chisinau Convention on Legal Assistance and Legal Relations in Civil, Family and Criminal Matters of 2002, which is often called the new, improved version of the Minsk Convention, since its provisions are largely similar to the provisions of the 1993 Convention. However, there are a number of short stories.

For example, Article 63 of the Chisinau Convention for the first time regulates the creation and activities of joint investigative-operational groups. Article 5 simplifies the procedure for communication between the competent justice institutions of the contracting parties. Article 20 includes new provisions on the confidentiality of information in the provision of legal assistance.

Unfortunately, the Republic of Uzbekistan has not yet ratified this Convention, which contains many progressive provisions.

\section{CONCLUSIONS}

In connection with the stated shortcomings of the application of the above provisions of the Minsk Convention by a number of CIS member states, it is expedient, in our opinion, to raise questions on improving the procedure for the exchange of information on the regional search databases for neighboring countries and on the inclusion in the Minsk Convention of January 22, 1993, country - initiated investigation of financial expenses for the maintenance of foreign nationals detained in the international wanted list, in the case of late submission of document required requesting party.

Summing up, it should be noted that a study of foreign experience found that in some European countries, the USA, Canada, Belgium, Turkey, Slovenia, Korea, Malaysia, India, Thailand and others, the legal mechanism is actively used as a measure to return wanted persons to the country to annul the validity of the passport (without deprivation of citizenship) of the wanted person. 
Cancellation of the validity of a passport as compared with extradition of a wanted person is not a costly measure for the State budget in comparison with extradition.

Based on the foregoing, in accordance with the law signed by the President of the Republic of Uzbekistan Shavkat Mirziyoyev on 08/28/2019, the Code of Criminal Procedure of the Republic of Uzbekistan introduced a rule regarding the suspension of a passport. More precisely, the code is supplemented by a new chapter 281 , which provides for the procedure for canceling the validity of a biometric passport for traveling abroad.

As well as the Criminal Procedure Code, articles 36, 381, 310 and 382 have been amended, defining the powers of the inquiry officer, investigator, and prosecutor, as well as the procedure for appealing and restoring rights regarding the cancellation of the validity of a biometric passport for traveling abroad.

Now, if there is reason to believe that the accused or defendant, who was wanted, can go abroad or move abroad using a passport, this passport can be suspended in court.

Suspension (cancellation) of the passport is carried out in order to prevent the accused, defendant from evading inquiry, preliminary investigation and trial, suppressing his further criminal activity, and ensuring the execution of the sentence.

Passport suspension refers to the temporary suspension of a passport, biometric passport, biometric passport for traveling abroad and a travel document of a stateless person.

At the same time, this procedure applies only to the accused or defendant, put on an interstate or international wanted list. It also does not entail the termination of citizenship of the Republic of Uzbekistan or the abolition of the legal status of a stateless person.

\section{REFERENCES}

[1] A. G. Kiryanov, Some issues related to the institution of extradition of criminals (extradition) in modern international law, International Criminal Law and International Justice, 2 (2008)19.

[2] B.Kh. Pulatov, Prosecutor's supervision over legality of the operational-search activity, using of its results as evidence, J. Law Research, 7 (2017) 48.

[3] B.Kh Pulatov, Experience of advanced foreign countries on the issues of increasing the effectiveness of the fight against crime and the prevention of legal abuses, J. of Law Research, 2 (2018) 34.

[4] Prosecutorial supervision: textbook, Yu.E. Vinokurov and etc., 9th ed., Publishing house Yurayt, 2010, 490 p. (Fundamentals of Sciences). ISBN 978-5-9916-0740-7.
[5] A.I. Boytsov, Extradition of criminals, Aslanov Publishing House "Legal Center Press", 2004, 795 p. ISBN 5-94201-379-9.

[6] The Criminal Procedure Code of the Republic of Uzbekistan: www.lex.uz

[7] Convention on the Transfer of Sentenced Persons, 1983.

http://www.coe.int/en/web/conventions/full-list/-/conventi ons/treaty/112

[8] Agreement between the Republic of Uzbekistan and Ukraine about transfer of persons sentenced to imprisonment, for further serving of punishment (Kiev, 19.02.1998).

[9] Agreement between the Republic of Uzbekistan and Turkmenistan on transfer of persons sentenced to imprisonment, for further serving of the sentence (Tashkent, 25.02.2009).

[10] Agreement between the Republic of Uzbekistan and the United Arab Emirates on the transfer of sentenced persons (Abu Dhabi, on 11/11/2014), entered into force on 21.05.2015.

[11] Agreement between the Republic of Uzbekistan and Georgia on the transfer of convicts to serve sentences in the state whose citizens they are (Tbilisi, 28.05.1996), entered into force on 23.04.1997.

[12] http://cis.minsk.by/reestr/ru/index.html\#reestr/ view/text?doc $=704$

[13] www.unodc.org/unodc/en/treaties/CTOC/ index.html

[14] www.unodc.org/unodc/en/treaties/CAC/index.html

[15] Legislation Series of the Republic of Uzbekistan. N 42, article 485, 2016. 